\title{
Front Matter: Volume 12086
}

, "Front Matter: Volume 12086," Proc. SPIE 12086, XV International Conference on Pulsed Lasers and Laser Applications, 1208601 (2 December 2021); doi: $10.1117 / 12.2625884$

SDIE Event: XV International Conference on Pulsed Lasers and Laser Applications, 2021, Tomsk, Russian Federation 


\title{
PROCEEDINGSOF SPIE
}

\section{Intemational Conference on Pulsed Lasers and Laser Applic ations}

\author{
Anton V. Klimkin \\ Maxim V. Thigub \\ Vic torF. Tarasenko \\ Editors
}

\section{2-17 September 2021}

\section{Tomsk, Russian Federation}

Organized by

Institute of Atmospheric Optics SB RAS (Russian Federation)

Institute of High Current Electronics SB RAS (Russian Federation)

Tomsk State University (Russian Federation)

Tomsk Polytechnic University (Russian Federation)

Sponsored by

Special Systems. Photonics (Russian Federation)

Young Scientists Council IAO SB RAS (Russian Federation)

TOPAZResearch and Inculc ation Enterprise (Russian Federation)

SP Equipment (Russian Federation)

Azimut Photonic s (Russian Federation)

CLZLtd. (Russian Federation)

Leningrad La ser Systems (Russian Federation)

Published by

SPIE

Volume 12086 


\section{PRO CEEDINGS OF SPIE}

\section{Volume 12086}


The papers in this volume were part of the technical conference cited on the cover and title page. Papers were selected and subject to review by the editors and conference program committee. Some conference presentations may not be available for publication. Additional papers and presentation recordings may be available online in the SPIE Digital Library at SPIEDigita lLibra ry.org.

The papers reflect the work and thoughts of the authors and are published herein as submitted. The publisher is not responsible for the validity of the information or for any outcomes resulting from reliance thereon.

Please use the following format to cite material from these proceedings:

Author(s), "Title of Paper," in XV Intemational Conference on Pulsed Lasers and Laser Applic ations, edited by Anton V. Klimkin, Maxim V. Trigub, Victor F. Tarasenko, Proc. of SPIE 12086, Seven-digit Artic le CID Number (DD/MM/YYYY); (DOI URL).

ISSN: 0277-786X

ISSN: 1996-756X (electronic)

ISBN: 9781510650480

ISBN: 9781510650497 (electronic)

Published by

SPIE

P.O. Box 10, Bellingham, Washington 98227-0010 USA

Telephone +1 3606763290 (Pacific Time)

SPIE.org

Copyright (C) 2021 Soc iety of Photo-Optic al Instrumentation Engineers (SPIE).

Copying of material in this book for intemal or personal use, or for the intemal or personal use of specific clients, beyond the fair use provisions granted by the U.S. Copyright Law is authorized by SPIE subject to payment of fees. To obta in permission to use and share articles in this volume, visit Copyright Clearance Center at copyright.com. Other copying for republic ation, resale, advertising or promotion, or any form of systematic or multiple reproduction of any material in this book is prohibited except with permission in writing from the publisher.

Printed in the United States of America by Curran Associates, Inc., under lic ense from SPIE.

Public ation of record for individual papers is online in the SPIE Digital Library.

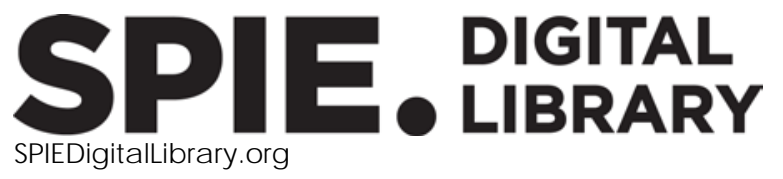

\footnotetext{
Paper Numbering: A unique citation identifier (CID) number is assigned to each article in the Proceedings of SPIE at the time of public ation. Utilization of CIDs allows artic les to be fully citable as soon as they are published online, and connects the same identifier to all online and print versions of the public ation. SPIE uses a seven-digit CID artic le numbering system structured as follows:

- The first five digits correspond to the SPIE volume number.

- The last two digits indicate publication order within the volume using a Base 36 numbering system employing both numerals and letters. These two-number sets start with $00,01,02,03,04$, $05,06,07,08,09,0 A, 0 B \ldots$ OZ, followed by 10-1Z, 20-2Z, etc. The CID Number appears on each page of the manuscript.
} 


\section{Contents}

\section{INTERNATIONALCONFERENCE ON PULSED LASERS AND LASER APPUCATIONS}

1208602 Photodegradation of bisphenol A in the presence of superfine mic rofiber polypropylene [12086-4]

1208603 Depth distribution of optical characteristics, bacteriochlorophylls and metagenomic profiles of bacterial communities in meromic tic lakes Trekhtzvetnoe and Elovoe in March 2021 [12086-54]

1208604 Yttrium-aluminum gamet ceramics with variable compositions for lighting applications [12086-86]

1208605 Three-stage power supply with a pulsed charge of the storage capacitance for metal vapor lasers [12086-92]

1208606 Simulation of the line profiles in the neon emission spectra in laser fields [12086-30]

1208607 Pulse-periodical $\mathrm{CO}_{2}$ laser operating at pressures up to 12 atmospheres [12086-46]

1208608 Pulse-periodical TEA-CO $\mathrm{CO}_{2}$ laser with wavelength tuning and pulse energy up to $1.5 \mathrm{~J}$ and duration up to $100 \mathrm{~ns}$ [12086-47]

1208609 TEA-N2 laser with a high level of average radiation power [12086-48]

12086 OA Computer modeling of XeCl-lasers [12086-65]

12086 OB Plasmonic jets and hooks: towards manipulation of light at the nanoscale [12086-8]

12086 OC Synthesis and investigation of iron-doped manganese aluminate spinel nanopowders and ceramics (Invited Paper) [12086-5]

12086 OD Photodegradation of aqueous solutions of phenoxyacetic acids under exc ilamps radiation [12086-1]

12086 OE The influence of the counterion type on the luminescent properties of organo-soluble europium complexes [12086-41]

$12086 \mathrm{OF}$ Interface features and electronic structure of $\mathrm{Bi}_{2} \mathrm{SiO}_{5} / \boldsymbol{\beta}_{-}-\mathrm{Bi}_{2} \mathrm{O}_{3}$ hetero-junction [12086-75]

12086 OG Study of the complexation reaction between substituted [2,2'-bipyridine]-6,6'diyl(phosphonates) and terbium ions [12086-53]

$12086 \mathrm{OH} \quad$ Optimization of laser radiation parameters for an effect on pigments, based on titanium dioxide $\left(\mathrm{TO}_{2}\right)$ [12086-85] 
12086 ol Femtosecond filamentation dynamics of synthesized coronary profile laser beam in air: numerical simulations [12086-11]

12086 0] Spectrum broadening of second hamonic femtosecond pulse in nonlinear crystal [12086-61]

12086 OK Large aperture stretc hers for high intensity laser systems [12086-50]

12086 OL Noncollinear coherent combining of few-cycle femtosecond pulses [12086-62]

12086 OM Modeling the propagation of high-power femtosecond laser radiation through an aerosol with nonlinear effects occuming in it [12086-23]

12086 ON Specifics of multiple filamentation formation for femtosecond laser radiation with topological charge [12086-16]

$1208600 \quad$ Tunable organic solid-state laser[12086-95]

12086 OP Quasi-neutrality of the relativistic laser-driven proton beam [12086-19]

12086 0Q Application of polanization lidars to study the onientation of crystalline partic les in ice clouds [12086-33]

12086 OR Consideration of selective and nonselec tive absomtion by watervapor and ozone when sounding atmospheric organic aerosol with a $\mathrm{CO}_{2}$ laser-based IR lidar [12086-82]

12086 OS Experimental comparison of merc ury cadmium telluride photodetectors with nitrogen liquid cooling and themoelectric cooling [12086-83]

12086 0T Multidisk laseramplifier with high pump power and cryogenic closed-loop cooling [12086-18]

12086 OU Vortex beam generation by means of control of the piston shift of a fiber aray using a phase forming DOE in active feedback loop [12086-55]

12086 OV Radiation mode structure of a laser unstable confocal cavity with additional feedback using a semitransparent plane mimor [12086-24]

12086 OW Features of radiation mode structure of a controlled laser unstable two-mimor resonator with deformable mimor [12086-25]

12086 0X Wireless undenwater optical communication with quantum key distribution [12086-13]

12086 OY Light scattering by large imegular ice crystals of cimus clouds [12086-22]

$120860 Z$ Research progress of real-time sensing LiDAR [12086-72]

1208610 Comparison of visible spectra of the accelerating gap of a pulsed electron accelerator in a vacuum diode with cathodes made of different materials [12086-93] 
1208611 A smart data control system for environment recognition lidar on Zynq SoCs (Invited Paper) [12086-42]

1208612 Analysis of the effic iency of methods for retrieval of vertical profile of atmospheric temperature from molec ular scattering at the main lidar of the Siberian lidar station [12086-94]

1208613 Peculiarities of a pokamp fomation from electrode with ceramic coating [12086-49]

1208614 Design features of the excimer lamp for UVB therapy [12086-56]

1208615 Features of the xenon excimer VUV spectra formation [12086-79]

1208616 Photonic hook: a new sub-wavelength-scale selfibending light beam [12086-7]

1208617 Fomation of asymmetric optical transmission spectra of a nanosecond discharge in extended shielded tubes upon resonant interaction of short laser pulses with excited neon atoms [12086-35]

1208618 Single wall carbon nanotubes and their conjugates with dimeric phthalocyanine complexes of Cu for optical limiters in the protection of photosensitive detectors and mic rooptoelectromec hanical systems [12086-27]

1208619 The efficiency of THz wave generation in $\beta$-BBO undervisible and IR fs pulse pump [12086-43]

12086 1A The dielectric tensor rotation angle and optical properties of a nonlinear crystal of bismuth triborate in the millimeter-wave range [12086-57]

12086 1B Generation of THz emission in femtosec ond laser-induced filament [12086-44]

$120861 \mathrm{C}$ Methods for detemining the residual amount of antibiotics in food [12086-2]

12086 1D Numerical simulation of the optical radiation absorption by dielectric mic rocapsules of different spatial shapes [12086-10]

12086 1E Physiological action of UVB radiation on wheat sprouts (Tritic um aestivum L) [12086-20]

12086 1F Application of machine leaming algonithms and laserabsomtion spectroscopy to solve the problem of detemining components with a low concentration in multic omponent gas mixtures [12086-78]

12086 1G Luminescent and physiological indices of bean plants under the treatment of seeds with epibrassinolide [12086-77]

12086 1H Informative feature selection method for Raman mic ro-spectroscopy data [12086-66]

12086 1l A new data on priming of plant seeds by UVB radiation [12086-21] 
12086 1] Efficiency of the phasor plot approach for the analysis of the antimic robial properties of nanopartic les using two-photon mic rosc opy [12086-84]

12086 1K Laser spectrosc opy of interactions of carbon nanopartic les with biomacromolec ules [12086-34]

$120861 \mathrm{~L} \quad$ DNA destruction underthe influence of VUV radiation [12086-58]

12086 1M Raman spectroscopy of blood plasma for cancer diagnosis [12086-59]

12086 IN Generation mode of nunaway electron beams with high amplitude in atmospheric pressure air [12086-88]

1208610 Multic hannel system for recording sub-nanosec ond pulses of gas and semic onductor radiation sources [12086-17]

12086 1P Diagnostics of the apokamp plasma parameters by emission spectra [12086-39]

$120861 \mathrm{E}$ Exciton cathodoluminescence of HIHP diamonds at elevated temperatures [12086-81]

12086 IR Application of quantum cascade laser to rapid detection of food adulteration (Invited Paper) [12086-26]

12086 1S Fraunhofer diffraction and the beam quality $\beta$ factor of a laser beam with sinusoidal wavefront [12086-74]

$120861 T \quad$ Induced absomtion spectra of crystal violet at various solvents [12086-3]

$120861 \mathrm{U}$ Active medium parameters of molecularnitrogen ions in air laser plasma [12086-60]

12086 IV Quantum chemical study of the spectral characteristics of fluorescein dyes bound to chitosan [12086-68]

12086 1W Numerical simulation of the ZnSe crystal doping profile influence on the threshold for the parasitic lasing development in a disk ZnSe:Fe ${ }^{2+}$ laser [12086-31]

12086 1X Performance analysis of multilayer Ge/ Si photodetec tor with quantum dots [12086-45]

12086 1Y Bismuth silicates: preparation by pulsed laser ablation and photocatalytic activity [12086-40]

$120861 Z$ High-intensity light channels formed during the propagation of high-power femtosec ond laser radiation in air[12086-14]

1208620 Channeling of femtosec ond laser pulses in the turbulent atmosphere [12086-15]

1208621 Detection of methane in the air using a laser Raman spectrometer [12086-76]

1208622 Sensitivity of copper bromide vapor brightness amplifier [12086-87] 
1208623 Phase control of an azimuthally polarized beam synthesized by an anay of fiber lasers [12086-51]

1208624 Formation of the scattering phase function in the interaction of ultrashort laser pulses with a drop and aerosol in a nonlinear mode [12086-32]

1208625 Prospects of controlling the propagation of high-power THtz radiation by passive optical elements inc luding 3D printed [12086-80]

1208626 Detailed study on optical properties of $\mathrm{L}_{2} \mathrm{~B}_{4} \mathrm{O}_{7}$ for down-conversion to millimeter waves [12086-38]

1208627 Development of an automated prototype of Trtz filter based on magnetic fluids [12086-37]

1208628 Temperature dependence of the absomption edge of synthetic diamond [12086-89]

1208629 Femtosecond laser-induced breakdown spectroscopy method for remote sensing of the aerosol atmosphere [12086-29]

12086 2A The image stabilization of laser radiation at the stand of the adaptive optical system [12086-28] 
Proc. of SPIE Vol. 12086 1208601-9

Downloaded From: https://www.spiedigitallibrary.org/conference-proceedings-of-spie on 26 Apr 2023 Terms of Use: https://www.spiedigitallibrary.org/terms-of-use 